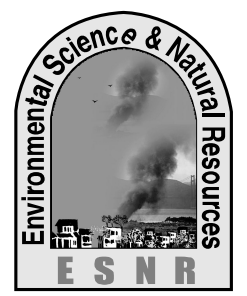

J. Environ. Sci. \& Natural Resources, 5(1): 83 - 87, 2012

ISSN 1999-7361

\title{
Development of Functional Beverage Based on Taste Preference
}

\author{
M. H. R. Bhuiyan, M. Shams-Ud-Din and M. N. Islam \\ Department of Food Technology and Rural Industries \\ Bangladesh Agricultural University, Mymensingh
}

\begin{abstract}
The experiment was conducted to develop functional beverage based on taste preference and studied its storage life. $3^{2}$ full factorial design was used to identify significant factor and base formulation. The "one factor at a time" optimization method was used to optimize formulation. The study showed that sweetness, sourness and their interaction have significant effect on overall acceptability in the development of functional beverage. Optimal combination per liter of functional beverage for men was found to be $73 \mathrm{mg}$ saccharin and $30 \mathrm{ml}$ of lime juice. For women, however, the optimal combination of each liter of functional beverage was $60 \mathrm{mg}$ saccharin and $47.5 \mathrm{ml}$ lime juice. Honey, garlic paste, black cumin seed powder, Sodium-benzoate, ascorbic acid, annatto color, citral, methyl phenyl acetate and water was common ingredients. Organoleptic taste test indicated that men and women preferred sweet and sour beverage respectively. TSS and $\mathrm{pH}$ showed linear whereas acidity and vitamin $\mathrm{C}$ concentration showed inverse relation with storage period. The RFT $\left(4 \pm 1{ }^{0} \mathrm{C}\right)$ storage ensured better retention of chemical and sensory properties than RMT $\left(30 \pm 2^{0} \mathrm{C}\right)$ storage. Significant storage (RFT) life of functional beverage for men and women was 5 to 6 and 4 to 5 months, respectively.
\end{abstract}

Key words: Acceptability, Men, Women

\section{Introduction}

The functional beverage contains different nutrient such as ascorbic acid, tocopherol, beta-carotene etc and offer benefits of dietary phytochemicals (Schnitter, 2001). Consumption of functional food would deliver health and wellness to consumer (Sharma, 2005) and it has no cytotoxicity and mutagenicity effects (Chen et al., 2009). Functional beverage category is one of the most significant drivers of new product development (NPD) in recent years (Sorenson and Bogue, 2005) as the consumer behavior is $13.79 \%$ influenced by healthy factor (Jaisam and Utama-ang, 2008). The market for functional drinks is expected to expand further due to the trend toward lifestyle diseases (McCoy, 2005) such as diabetes, hypertension etc.

The main components of soft drinks are water, acidulants, flavorings, food colors, preservatives, and other functional ingredients (Ashurst, 1998). The use of natural ingredient make the drinks more acceptable (Sharma, 2005). There is variation in product acceptability among consumer as the taste blindness occurs in $22.2 \%$ women and $25.9 \%$ men (Meyer, 2007). And there is also difference in beverage consumption between men and women (Young and $\mathrm{Ju}, 2009$ ). So the functional foods need to be promoted as convenient, nutritious and tasty formulations with specific health benefits (Sharma, 2005) for the target population.

Black cumin seed is well-known as holy seed. The principal active ingredient is crystalline nigellone, and the seed contains 15 amino acids, carbohydrates, fatty acids, volatile oils, alkaloids, dietary fiber and different minerals. It has many medicinal uses such as those suffering from diabetes, hypertension, laziness and fatigue, sexual impotency etc. The seeds lower blood sugar levels. Honey is curative and it cleanses the blood, boosts its formation and circulation and prevents arteriosclerosis. Honey is effective in controlling blood pressure, and preventing strokes as it reduced total cholesterol, triglycerides, C-reactive protein, homocysteine, blood sugar and increased HDL cholesterol by 7\%, 2\%, 7\%, 6\%, 6\% and 2\% respectively. The main components of garlic are allicin, $\quad \gamma$-glutamyl-S-allylcysteine and allicin transformed products (Roy et al., 2006). It lowers blood pressures a little (9\% to $15 \%$ ), LDL cholesterol and also reduce the possibility of strokes and thrombosis. Lime is effective in cholesterol reduction.

There is a big market for the more attractive and expensive but less effective general synthetic beverage. The development of low cost health beneficial beverage is a demand of time. A major portion of people always avoid the general synthetic beverage from the stand point of hypertension, diabetes and obesity etc. So, a beverage that satisfies need based demand of the majority of the population including those suffering from obesity, hypertension, and diabetes should be developed. Past research reports indicate that development of functional beverage based on taste preference was not reported so far. Keeping this view in mind, the present work was undertaken with the following objectives; (1) To find out optimal formulation of functional beverage 
based on taste preference, and (2) To study the storage-life of the developed functional beverage.

\section{Materials and Methods}

The experiment was conducted in the laboratory of the Department of Food Technology and Rural Industries, Bangladesh Agricultural University, Bangladesh. The major ingredients were collected from local (K-R) market. Different chemicals and materials were used from the laboratory stock.

\section{Preparation of major ingredients}

The Contaminant free, thoroughly washed, vacuum dried black cumin seed were roasted and then grinded and repeatedly screened to find finest powder form. Honey was prepared by screening with fine screen. The lime juice was collected by applying the method as described by Cruess (1958). Garlic paste was made from pre-prepared clove using mortar-pestle and cotton cloth.

\section{Formulation fundamentals}

Water can be used up to $98 \%$ (v/v) when high intensity sweeteners are used in beverage (Ashurst, 1998). The toxic level of black cumin seed is $\geq 25$ grams and heating of seed is mandatory. Mixture of black cumin seed and garlic, in the ratio of 1:1 has antimicrobial effects (Roy et al., 2006). The typical use of ascorbic acid is <100 ppm (Ashurst, 1998). The 180 to $300 \mathrm{~K}$-calories a day provided from honey is sufficient. The European Parliament and Council Directive permit the use of saccharin at $80 \mathrm{mg} / \mathrm{l}$ in energy reduced/sugar free-water/dairy/fruit based drinks (Ashurst, 1998). The respective average use of methyl phenyl acetate and the citral are $2.4 \mathrm{ppm}$ and 17.6 ppm (Meyer, 2007). Color can be used but must not exceed $100 \mathrm{mg} / \mathrm{l}$ (Ashurst, 1998). Benzoate is used in beverage (Frazier and Westhoff, 2007). The European Directive permits $150 \mathrm{mg} / \mathrm{l}$ Benzoic Acid for soft drinks consumable without dilution (Ashurst, 1998).

\section{Design of experiment}

Primarily the $3^{2}$ full factorial design was used as strongly recommended by Mon and Chan (2007). The main factors were sweetness from saccharin $(40,60$, and $80 \mathrm{mg}$ ) and sourness from lime juice (10, 30 and $50 \mathrm{ml}$ ) with three level of each factor, as the soft drink is sweetened water- based beverage, usually with a balancing acidity (Ashurst, 1998). The "one factor at a time" optimization method as described by Box and Draper (1987) was applied. Polynomial model having $\mathrm{R}^{2}$ value a minimum of 0.85 (Henika, 1982) was used to optimize formulation.

\section{Preparation of beverage}

The screened water was boiled at around $100^{\circ} \mathrm{C}$ and then cooled to $30^{\circ} \mathrm{C}$. The pre-prepared ingredients were mixed in fixed amount with the required amount of water. Then $100 \mathrm{ppm}$ of Sodium-benzoate was added with the beverage and packed in previously sterilized glass bottles.

\section{Sensory evaluation}

The consumer acceptability of the developed product was evaluated by a taste-testing panel (five males and five females) using 1-9 point Hedonic Rating Test (HRT). The panelist scores were analyzed with software.

\section{Chemical analysis}

Acidity, $\mathrm{pH}$, total soluble solids and vitamin $\mathrm{C}$ content were determined. The analysis of moisture content, ash, fat and protein was performed according to AOAC (2005).

\section{Results and Discussion}

\section{Significant factors}

As $3^{2}$ full factorial design was used, the effect of main factors and their interaction were analyzed with Factorial ANOVA (Analysis of Variance) as reported by (Mon and Chan, 2007) to know the significant factor. The main factor sweetness and sourness and also their interaction was statistically significant at $\mathrm{P}<0.05$.

\section{Base sample}

Among the primary samples, DMRT was applied as it commonly used in agricultural research (Granato et $a l ., 2011)$ and the best ranked sample was identified as base sample. From Table 1, the highest score (6.2) was given by combination A2B2, ranked "Like slightly" and identified as base sample. The combination $\mathrm{A} 3 \mathrm{~B} 2, \mathrm{~A} 2 \mathrm{~B} 3, \mathrm{~A} 1 \mathrm{~B} 2$ and $\mathrm{A} 2 \mathrm{~B} 1$ are statistically insignificant at $\mathrm{P}<0.05$ as they are suffixed by same letter. And the difference among the combination A3B3, A1B3 and A3B1 were statistically insignificant as suffixed by same letter at $\mathrm{P}<0.05$. The lowest value (3.4) was found in combinationA1B1 and preceded by $\mathrm{A} 3 \mathrm{~B} 3$. The formulation of the base sample (A2B2) for 1litre was as follows: $1 \mathrm{~g}$ black cumin seed (powder), $1 \mathrm{~g}$ garlic paste (screened), $10 \mathrm{ml}$ honey, $100 \mathrm{ppm}$ sodiumbenzoate, $100 \mathrm{ppm}$ ascorbic acid, $100 \mathrm{ppm}$ annatto, $15 \mathrm{ppm}$ citral, $2 \mathrm{ppm}$ methyl phenyl acetate, $60 \mathrm{mg}$ saccharin, $30 \mathrm{ml}$ lime juice and $960 \mathrm{ml}$ water. 
Table 1. Duncan's multiple range test (DMRT) value for over all acceptability

\begin{tabular}{|l|c|c|c|c|c|c|c|c|c|}
\hline Combination & A1B1 & A1B2 & A1B3 & A2B1 & A2B2 & A2B3 & A3B1 & A3B2 & A3B3 \\
\hline Mean & $3.4^{\mathrm{d}}$ & $5.4^{\mathrm{b}}$ & $4.6^{\mathrm{c}}$ & $5.3^{\mathrm{b}}$ & $6.2^{\mathrm{a}}$ & $5.5^{\mathrm{b}}$ & $4.7^{\mathrm{c}}$ & $5.6^{\mathrm{b}}$ & $4.2^{\mathrm{c}}$ \\
\hline
\end{tabular}

\section{Effect of saccharin on acceptability}

From Fig.1, the men and women response changes with change in saccharin as proposed by Bartoshuk (1977) but in opposite direction as reported by Ohrwall (1901) and their complete response trends statistically followed Second Degree Polynomial (SDP) model. The $\mathrm{R}^{2}$ value was 0.925 and 0.854 for men and women respectively and was highly accepted as reported by Montgomery (2009) and Henika (1982).



Fig. 1. Relationships between sweetness from Saccharin and overall acceptability

Two SDP model describing effect of saccharin on overall acceptability are:

For men: Overall acceptability, $Y=-0.002 X^{2}+0.292 X-3.187(X=m g$ of saccharin $)$

For women: Overall acceptability, $Y=-0.001 X^{2}+0.138 X+2.526(X=m g$ of saccharin $)$.

\section{Effect of lime juice on acceptability}

From Fig. 2, the men and women complete response trends statistically followed second degree polynomial (SDP) model. The respective $\mathrm{R}^{2}$ value was 0.961 and 0.861 for men and women response model and was highly accepted as noted earlier.

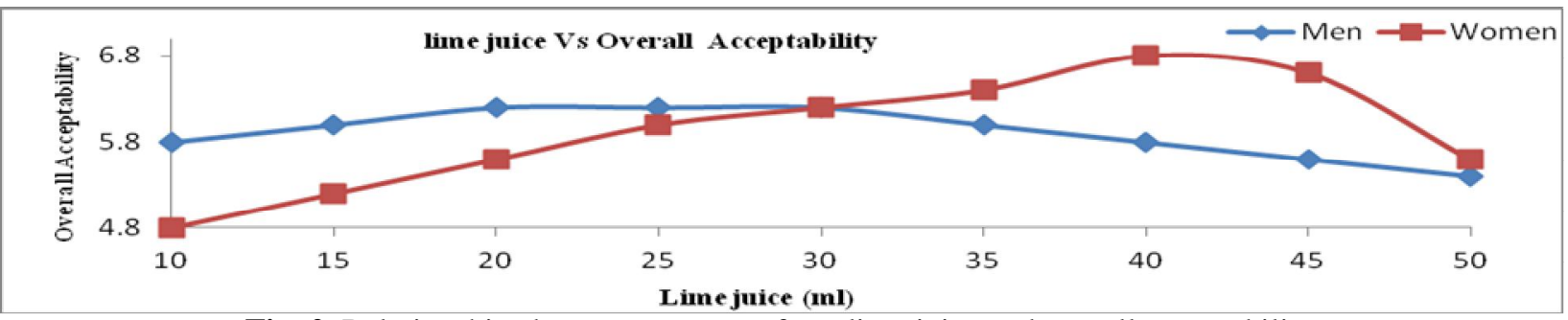

Fig .2. Relationships between sourness from lime juice and overall acceptability

Two SDP model describing effect of lime juice on overall acceptability are:

For men: Overall acceptability Score, $Y=-0.001 \mathrm{X}^{2}+0.072 \mathrm{X}+5.526(\mathrm{X}=\mathrm{ml}$ of lime juice $)$.

For women: Overall acceptability Score, $\mathrm{Y}=-0.002 \mathrm{X}^{2}+0.190 \mathrm{X}+2.98(\mathrm{X}=\mathrm{ml}$ of lime juice $)$

\section{Optimal formulation}

The SDP model equation 1 and 3 represent men response while women response is represented by equation 2 and 4 . As per equation 1 the highest $\mathrm{Y}$ value is 7.471 when $X$ value is $73 \mathrm{mg}$ saccharin. The highest $\mathrm{Y}$ value is 6.822 when $\mathrm{X}$ value is $36 \mathrm{ml}$ lime juice (equation: 3 ). As per equation 4 the highest $\mathrm{Y}$ value is 7.493 when $\mathrm{X}$ value is $47.5 \mathrm{ml}$ lime juice, while equation 2 predicts the highest $\mathrm{Y}$ value (7.287) for $69 \mathrm{mg}$ saccharin. Equation 1 will be used to optimize formulation for men as this $\mathrm{Y}$ value, 7.471 is greater than 6.822 . Similarly for women equation 4 will be used to optimize formulation (7.493>7.287). Hopefully the optimized formulated beverage for men and women as per equation 1 and 4 respectively when tasted organoleptically, the products would be ranked as "Like moderately" whereas the base sample (A2B2) was ranked "Like slightly" as described by Ranganna (1991).

\section{Laboratory attributes}

From Table 2, the initial TSS of both functional beverage for men and women was $2 \%$ and the respective acidity was $0.282 \%$ and $0.333 \%$. Initial 
vitamin $\mathrm{C}$ concentration of functional beverage for men and women were 24.2 and $34.1 \mathrm{mg} / 100 \mathrm{ml}$ respectively. It was observed that TSS increased and acidity as well as vitamin $\mathrm{C}$ concentration decreased as storage time increased. Similar observation was made by Saron et al. (2007). TSS percentage may be increased due to loss in moisture content during storage and acidity might decrease due to degradation of vitamin C. Factors responsible for vitamin C losses are; temperature, oxidation, acidity, $\mathrm{pH}$ and metal trace (Villota and Hawkes, 1992). Loss of vitamin C at constant temperature follows first order reaction kinetics. The rate constant is dependent on inverse absolute temperature by an Arrhenius type relationship. It was also observed that the changes of TSS, vitamin $\mathrm{C}$ and acidity were more pronounced in RMT storage than RFT storage. These findings are in agreement with Roy et al. (1997) who showed that storage at $4 \pm 1^{0} \mathrm{C}$ (RFT) ensure maximum retention of chemical and sensory properties in comparison to storage at higher temperature.

Table 2. Changes of TSS, acidity and vitamin C of developed beverage at (RMT) and (RFT) storage.

\begin{tabular}{|c|c|c|c|c|c|c|c|}
\hline \multirow[b]{2}{*}{ Beverage } & \multirow[b]{2}{*}{ Days } & \multicolumn{3}{|c|}{ RMT (Room Temperature) } & \multicolumn{3}{|c|}{ RFT (Refrigerator Temperature) } \\
\hline & & $\begin{array}{c}\text { TSS } \\
\% \\
\end{array}$ & Acidity (\%) & Vitamin C $(\mathrm{mg} / 100 \mathrm{ml})$ & $\begin{array}{c}\text { TSS } \\
\%\end{array}$ & Acidity (\%) & Vitamin C (mg/100 ml) \\
\hline \multirow{7}{*}{ Men } & 0 & 2.0 & 0.282 & 24.2 & 2.0 & 0.282 & 24.2 \\
\hline & 30 & 2.1 & 0.276 & 15.0 & 2.0 & 0.279 & 16.46 \\
\hline & 60 & 2.1 & 0.248 & 8.954 & 2.1 & 0.256 & 11.13 \\
\hline & 90 & 2.2 & 0.213 & 5.08 & 2.1 & 0.238 & 8.23 \\
\hline & 120 & 2.2 & 0.186 & 3.63 & 2.1 & 0.216 & 5.814 \\
\hline & 150 & 2.3 & 0.142 & 1.791 & 2.2 & 0.20 & 3.87 \\
\hline & 180 & 2.3 & 0.112 & 1.02 & 2.2 & 0.196 & 2.42 \\
\hline \multirow{7}{*}{ Women } & 0 & 2.0 & 0.333 & 34.1 & 2.0 & 0.333 & 34.1 \\
\hline & 30 & 2.1 & 0.269 & 20.46 & 2.0 & 0.279 & 23.19 \\
\hline & 60 & 2.1 & 0.205 & 11.25 & 2.1 & 0.247 & 13.64 \\
\hline & 90 & 2.2 & 0.18 & 7.50 & 2.1 & 0.226 & 8.87 \\
\hline & 120 & 2.2 & 0.164 & 3.75 & 2.1 & 0.208 & 6.14 \\
\hline & 150 & 2.3 & 0.14 & 1.88 & 2.1 & 0.198 & 4.09 \\
\hline & 180 & 2.3 & 0.102 & 1.023 & 2.2 & 0.187 & 2.52 \\
\hline
\end{tabular}

\section{Storage stability}

The storage life was determined using "paired-t" test, as the period until there was no statistically significant change $(\mathrm{P}<0.05)$ in overall acceptability. From Table.3, significant RFT storage life of functional beverages for men was more than 5 months as the $\mathrm{P}$ value was $0.07>0.05$ and less than 6 months as the $\mathrm{P}$ value was $0.016<0.05$. And the $\mathrm{P}$ values also indicate that, significant RMT storage life of functional beverages for men was 4 to 5 months. Significant RFT storage life of functional beverages for women was more than 4 months as the $\mathrm{P}$ value was $0.178>0.05$ and less than 5 months as the $P$ value was $0.016<0.05$. And the $P$ values $0.374>0.05$ and $0.016<0.05$ indicate that, significant RMT storage life of functional beverages for women was 3 to 4 months. Functional beverage for both men and women showed higher storage stability in RFT than RMT. This is due to the fact that at higher temperature rate constants for various deteriorative reactions are higher leading to lower storage stability at RMT. Similar observations were made by Roy et al. (1997).

Table 3. The change of overall acceptability of beverage

\begin{tabular}{|c|c|c|c|c|c|c|c|c|c|c|}
\hline \multirow{3}{*}{ Beverage } & \multirow{3}{*}{ Panelist } & \multicolumn{9}{|c|}{ Overall Acceptability } \\
\hline & & \multirow[t]{2}{*}{0 day } & \multicolumn{2}{|c|}{90 day } & \multicolumn{2}{|c|}{120 day } & \multicolumn{2}{|c|}{150 day } & \multicolumn{2}{|c|}{180 day } \\
\hline & & & RMT & RFT & RMT & RFT & RMT & RFT & RMT & RFT \\
\hline \multirow{6}{*}{ Men } & 1 & 7 & 7 & 7 & 6 & 6 & 6 & 6 & 6 & 6 \\
\hline & 2 & 7 & 7 & 7 & 7 & 7 & 7 & 7 & 6 & 7 \\
\hline & 3 & 8 & 8 & 8 & 7 & 7 & 7 & 7 & 7 & 7 \\
\hline & 4 & 7 & 7 & 7 & 7 & 7 & 6 & 7 & 6 & 6 \\
\hline & 5 & 8 & 7 & 7 & 7 & 7 & 7 & 7 & 6 & 7 \\
\hline & \multicolumn{2}{|c|}{$\begin{array}{c}\text { Significance, } \\
\text { P value }\end{array}$} & 0.374 & 0.374 & 0.070 & 0.070 & 0.016 & 0.070 & 0.004 & 0.016 \\
\hline \multirow{6}{*}{ Women } & 1 & 7 & 7 & 7 & 7 & 7 & 6 & 6 & 6 & 6 \\
\hline & 2 & 7 & 7 & 7 & 6 & 7 & 6 & 7 & 6 & 6 \\
\hline & 3 & 8 & 8 & 7 & 7 & 7 & 7 & 7 & 6 & 7 \\
\hline & 4 & 7 & 7 & 7 & 6 & 7 & 6 & 6 & 5 & 6 \\
\hline & 5 & 8 & 7 & 8 & 7 & 7 & 6 & 7 & 6 & 6 \\
\hline & \multicolumn{2}{|c|}{$\begin{array}{c}\text { Significance, } \\
\text { P value }\end{array}$} & 0.374 & 0.374 & 0.016 & 0.178 & 0.004 & 0.016 & .003 & 0.004 \\
\hline
\end{tabular}




\section{Conclusions}

The composition of functional beverage was determined based on the taste preference of men and women. Men showed likings for sweetness and women showed likings for sourness. The increase in TSS was directly whereas acidity and vitamin C concentration change was inversely related with storage period. The RFT storage ensured maximum retention of chemical and sensory properties compared to RMT storage. Significant storage (RFT) life of functional beverages for men and women was 5 to 6 and 4 to 5 months, respectively.

\section{References}

Ashurst, P.R. 1998. The Chemistry and Technology of Soft Drinks and Fruit Juice. Sheffield Academic Press Ltd, England.

AOAC Methods. 2005. Official Method of Analysis $12^{\text {th }}$ edition. Association of Official Agricultural Chemists, Washington, D.C.USA.

Bartoshuk, L. M. 1977. Modification of Taste Quality. In G. Birch, J. Brennan, and K. Parker (Eds.), Sensory Property of Food. England: Applied Science Publisher LTD.

Box, G. E. P. and Draper, N. 1987. Empirical modelbuilding and response surface (1st ed.). New York, John Wiley.

Chen, L.; Chang-Wen, C.; and Wu-She C. 2009.The antimutagenic and antioxidative activity for functional formula beverage. Taiwanese Journal of Agricultural Chemistry and Food Science, 47(6): 277-284.

Cruess, W. V. 1958.Commercial Fruit and Vegetable Products, 4th Ed. Mcgraw-Hill Book Co, Inc., USA.

Frazier, W.C. and Westhoff, D.C. 2007. Food Microbiology, 4th Ed. Tata McGraw-Hill Publishing Company Ltd, New Delhi, India.

Granato, D; Branco, G.F and Verônica M. 2011. Experimental design and application of response surface methodology for process modelling and optimization: A review. Food Research International.

Henika, R. B. 1982. Use of response-surface methodology in sensory evaluation. Food Technology, 36: 96-101.

Jaisam, S. and Utamaang, N. 2008. Factor analysis of consumer behavior of tea beverage. Proceedings of the $46^{\text {th }}$ Kasetsart University Annual Conference, 147-154.
McCoy, J. 2005. Functional foods and drinks - a market overview. Fruit-Processing, 146-149.

Meyer, L.H. 2007. Food Chemistry. Reinhold Publishing Corporation, New York, USA.

Mon, S. Y. and Li-Chan, C. Y. 2007. Changes in aroma characteristics of simulated beef flavour by soy protein isolate assessed by descriptive sensory analysis and gas chromatography. Food Research International, 40(10): 1239-1248.

Montgomery, D. C. 2009.Design and analysis of experiments (5th ed.). New York: Wiley \& Sons, Inc. $672 \mathrm{p}$.

Ohrwall, H. 1901. Skand.Archiv. Physiol., 11, 245p.

Ranganna.S.1991. Handbook of Analysis and Quality Control for Fruit and Vegetable Products, 2nd Ed. Tata McGraw-Hill Publishing Company Ltd, New Delhi, India.

Roy, A.K.; Joshi, S. and Nathan, N. 1977. Effect of homogenization on Sensory Quality and Rheological Characteristics of pulp and Beverage from Ripe Dushehari Mango. Journal of food Science and Technology, India , 212-217.

Roy, J.; Shakleya, D. M.; Callery, P. S. and Thomas, J. G. 2006. Chemical constituents and antimicrobial activity of a traditional herbal medicine containing garlic and black cumin. African Journal of Traditional, Complementary and Alternative Medicines, 3(2): 1-7.

Saron, E.S.; Dantas, S.T.; Menezes, H.C.; Soares, B.M.C. and Nunes, M.F. 2007. Sensorial stability of ready to drink passion fruit juice packaged in tinplate cans. Ciencia e Tecnologia de Alimentos, 27(4): 772-778.

Schnitter, C. 2001. Liquid fruit and vegetable power nutritional beverages. European-Food-andDrink-Review, 27-29.

Sharma, R. 2005. Market trends and opportunity for functional dairy beverage. Australian Journal of Dairy Technology, 60(2):195-198.

Sorenson, D., and Bogue, J. 2005. Market-oriented new product design of functional orange juice beverages: a qualitative approach. Journal of Food Products Marketing, 11(1): 57-73

Villota and Hawkes. 1992. Kinetics in food System.In:Hand Book of Food Engg. Edt. by Heldman, D.R 1992. 58-60pp.

Young, Kim-Seok. and Ju, Lee-Yun. 2009. Seasonal and gender differences of beverage consumption in elementary school students. Nutrition Research and Practice, 3(3): 234-241. 